\title{
THE SUPREME COURT AND PRIVATE RIGHTS
}

\section{BY EDVIN BORCHARD。}

I.

Some of the social-political theories which influenced the framers of the Constitution were derived from Locke, Hume, Harrington, Coke and Blackstone. These men were less concerned with forms of government than with the relation between society as a whole and its individual members. They were sure that the individual possessed certain indefeasible, primordial rights and that government was designed to protect these rights against encroachment by the state or by classes within it. Perhaps the most important of these private rights was that of property, associated by Locke with liberty and often identified with it. ${ }^{1}$ Thus, the effort of the British Parliament to levy distasteful taxes and impose commercial restrictions was pictured in America as a challenge to fundamental theories of government.

But essentially the revolution was not economic in character. The American leaders were quite satisfied with the economic order, but were disturbed by the British threat to what they considered vested rights. In the beginning they were as distrustful of the populace as they were of the distant government. Their revolutionary philosophy developed slowly. It is well known that Franklin and Hamilton were not averse to a limited monarchy. But when the break with England became irrevocable in 1775 , and it proved necessary to arouse the people actively to vindicate their sense of grievance, the virtues of democracy were extolled and homage paid to the common man as the source of authority. The "natural

${ }^{*}$ Hotchkiss Professor of Law, Yale Law School. The article is a slight revision of a paper read at the meeting of the American Political Science Association at Philadelphia, December 28, 1937.

1. Locke, Ax Essay Concerning the True Oragiwal Extent aid Exd of Chil Governarent (1690), the second of Two Treatises of Government (Everyman's ed. 1924). That the philosopher Locke was not as precisè or modern in his conceptions of "property" as subsequent glosses would make it appear, is shown by Walton Hamilton in his article Property-According to Locke (1932) 41 YALE L. J. 864. In that article will also be found references to Hume and other philosophers of the seventeenth and eighteenth centuries, whose ideas were later employed to defend what the revolutionary Fathers undertook to accomplish. 
rights" were now extended to him, with Patrick Henry and Thomas Paine the major exponents of the theory. Jefferson recorded the aspiration in classic documents. But when the war was over the more conservative note reappeared and the "imprudence of democracy", especially in its disrespect for property, again troubled the framers of the Constitution. While they talked about universal suffrage, in fact they left the qualification of the voters to the States, where the ownership of property was still a condition of the franchise.

The framers in 1787, combining a mercantilist policy of State promotion of commercial interests with a modified laissez faire economy, were primarily concerned with the distribution of governmental powers to balance the influence of small against large States and to define the jurisdiction of the federal government. While the theory of checks and balances had been developed by continental political theorists and much had been learned from the defective Articles of Confederation and from State constitutions, the framers had no real precedents for the actual division of governmental powers. They were able to convince the ratifiers that their plan was workable, and since then the world has stood in admiration of the highly original architects of a federal system that has withstood the ravages of war and economic disaster. For while political and social changes have occurred and the suffrage has been extended to those whose "imprudence" Hamilton feared, the framework still stands, although the federal jurisdiction has been expanded much beyond the original conception. Possibly these alterations would not have been accepted but for their benevolent ratification by the judges of the Supreme Court.

The liberalism which upheld private freedom from governmental restraint has in late years suffered a schism between two schools whose struggle for dominance threatens liberalism itself. During the broad laissez faire economy of the 19th century, the division was not always noticeable. The civil liberty of the private individual and the freedom of the entrepreneur or businessman were hardly distinguished. They were both protected by constitutional guaranties. When liberty and property were twice mentioned in juxtaposition in the same sentence of the Constitution, their different connotations were hardly perceived. Property and accumulations, with rather unanimous support, enlisted the aid of several constitutional clauses and extra-constitutional "principles", focused on the doctrine of vested rights, to prevent or limit governmental restraints.

The schism between the schools appeared with the improvement in the machine, the growth of large-scale industry and the increase in population toward the end of the 19th century. John Austin. Herbert Spencer and William Sumner extolled the virtues of rugged individualism and the rigors of unhampered competition, and challenged as a return to Toryism 
much of the increasing factory or social legislation and governmental regulation. Thus, Justice Peckham and his colleagues in the Lochner case, Justice Sutherland and his colleagues in the Adkizs minımum wagre case, and the American Liberty League in 1935 had behind them historical tradition and a political philosophy which they could with a certain sincerity, misapplied to be sure, identify with Lockian liberalism.

What this school of thought too lightly overlooked was the change in the social status of private enterprise as vell as the contribution made to liberalism by the humanitarians, who were more interested in the liberty of the common man than in that of the businessman. The pragmatism of the humanitarians led them to question the social use that the laissez faire entrepreneurs were making of their asserted freedom from governmental restraint. They found that the liberty of the factory owner worked out too often in the oppression of the laborer. The humanitarians therefore ranged themselves on the sides of governmental regulation of industry and of labor union organization, while insisting upon the personal privileges and immunities of the Bill of Rights against both government and industry. They were willing to abandon the theology of natural or inalienable rights, and while openly admitting, to the disgust of men like Herbert Spencer, that both "liberty" and "property" were creatures of the state and law and subject to public control, they nevertheless insisted on the State's observing a broad interpretation of the constitutional privileges of the common man.

Jeremy Bentham was among their leaders in England, and Henry Carter Adams among their leaders in the United States. Successful politicians have known how to exploit universal suffrage to produce victories for this view of liberalism. Whether they were always sincere or whether they always tempered sentiment with wisdom is a debatable question. The danger is that in its devotion to governmental regulation the humane school may unwittingly prove willing to support some form of state collectivism or authoritarianism, which might easily lead to the death of that flexibility and open-mindedness, that appreciation of balance and compromise which we associate with liberalism, and hence to the passing of democracy itself. H. G. Wells, noting the trend, has remarked that the humanitarian liberals lost their great opportunity when they shied away from the mild reforms of the socialists of the late 19th century and thus exposed society to the tempests of the class conflict. A fundamental cleavage in ideologies would make the democratic process itself impossible.

The Constitution was expected to express the common bases of general agreement, around which the minor differences of public and party policy might play. It has proved, by the accommodating flexibility of a relatively sensitive Supreme Court, adequate to meet so profound a transition as that from laissez faire to a publicly controlled economy. Only 
once did the cleavages prove too serious to accept judicial decision or compromise, and even then violence might not have come had moral crusaders not injected self-righteousness into the issue. It would be a pity if strongly-held views of economic polity-which always implies a vast element of conjecture, hope and undisciplined emotion, with the least experienced the most certain of their panaceas-should convert a guess concerning methods of achieving the more abundant life into so fundamental an issue as to defy constitutional adjustment.

\section{II.}

In the long evolution of social policy from 1787 to the present, the Supreme Court has necessarily played a vital part. Discussion will not soon end as to whether the Court usurped authority in assuming the function of judicial review and ostensibly final interpreter of the Constitution. But that its position has met with popular acquiescence and general approval, the common stand of the defenders of business liberty and civil liberties against the 1937 attempt to weaken the Supreme Court would indicate. Doubtless the Court has on occasion failed to reflect popular conceptions, but these occasions have been infrequent and before long, as in the cases of the Eleventh and Sixteenth Amendments, the Court was either overruled in the constitutional way or, as in the case of the Wagner Act decisions, ${ }^{2}$ the Court found it possible to interpret the broad words of the Constitution so as to give effect to the prevailing demand.

It is trite to remark that but for the capacity to adjust the construction and application of such terms as "liberty", "due process", "interstate commerce", "obligation of contract" to new conditions and new facts, the Constitution would long since have had to be rewritien. Its very virtue lies in this adjustability. Question may be raised as to whether the Supreme Court rather than some other agency should have been the official interpreter, but it can probably be affirmed that no other agency would have proved so satisfactory or would have preserved so effectively that balance between stability and change which every living organism exhibits. As Mr. Justice Cardozo remarked in his Storrs Lectures delivered at the Yale Law School in 1921, "liberty" is not defined and does not mean "the same thing for successive generations". This must necessarily be so, because the changing political conceptions of the relationship between private freedom and public restraint determine the meaning at any given time to be assigned to such abstractions as "liberty" and even "property". Locke's view of property as the product of one's personal labor has greatly altered with the coming of the industrial system and

2. National Labor Relations Board v. Jones and Laughlin Steel Corp., 301 U. S. I (1937) and following cases in that volume. 
finance capitalism. Social requirements necessarily curtail individual freedom, and the Court has a delicate function to perform in supernising the proper balance between them, involving, as the issue dues, political, economic, and social considerations. The Court's judgment is expressed in its ad hoc definition of such terms as "liberty" or "property", on the one hand and "due process", the correlative, on the other.

Criticisms of the Court are centered not on the fact of flexibility of construction and interpretation, which is inescapable and indeed desirable, but on the question whether the Court correctly reflects the prevailing mores and whether, in setting aside legislation of a social or economic character, it has failed to attribute adequate weight to the political opinion of social relationships expressed by the legislature and has unwisely undertaken to substitute its own political views of social poilicy. When the Court maintains the "liberty" of the individual to accept as low wages or as long hours as he "chooses", the lhumane liberals rise in their wrath at the perversion. Considering the scope of the power, derived from the broad terms of the Fourteenth Amendment and thence transferred to the Fifth, and considering the fact that the Court undertook, with public acquiescence, to "rewrite" the Fourteenth Amendment," of whose original purpose practically nothing is left, the Court's performance over the long period of 150 years must be rated exceptionally high.

But power practically always invites abuses, and it is not surprising that the Supreme Court has been tempted. Much of the criticism arose during the years 1922 to 1935, when a conservative majority stond rigidly on its own views of economic policy to defeat price and other forms of business regulation, invoking the "due process" clause as allegedly inexorable authority. When the New Deal came along the members of this majority proved unusually adamant, and unfortunately relied upon their supposed impregnability to frustrate social experiments which a wiser use of their great powers would have sustained. The result, as had happened before, was to invite attack upon their lack of self-restraint, culminating in a formidable Presidential assault upon the integrity and independence of the Court itself. While the method was unfortunate, the lesson was not in vain. We may now see less dissipation of the exceptionally valuable power of judicial review either on such minor and debatable subjects as price and wage regulation or on such equally economic or political questions as were involved in the Agricultural Adjustment Act, the NRA and similar large-scale sncial experiments. In neither of these extreme cases is it wise for the Court to interfere with the legis-

3. Justice Field, arch-defender of private initiative, thought it an "estraurdinary" usurpation" for the Court to supervise police power legislation. Barbier v. Connolly; 113 U. S. 27, 30 (1885). He admitted that "special burdens are often necessary for general benefits." 
lature, certainly on social or "due process" grounds. For these experiments the political branches must assume responsibility, and economic "laws" will usually dictate the verdict. The power ought mainly to be used in the intermediate ground where the individual or single corporation seeks protection against improper discrimination, oppression or arbitrariness. A restraint in the use of the power will be likely to insure its longevity.

The charge that the United States is a "government of judges" is not necessarily derogatory. The restraint exerted by the courts on a volatile and gullible population, over-confident in the faith that legislation can cure individual and social ills, has saved many a mistake. And far from being ashamed of the device, it is a mark of social advancement to have developed a popular willingness to bow, even grudgingly, to the decrees of Nine Old Men. No error of theirs is necessarily fatal to the community, as have on occasion been the errors of the Legislature and the Executive. American history exemplifies the fact that the community has ways of correcting judicial errors, if the Court's own corrective process is too slow. We know also that the Court for the most part has no occasion to pass upon many of the violations of civil liberties, which rest in the hands of local communities and do not reach the courts. Respect for these constitutional guaranties is a matter of education and community feeling. And when the Court is accused of "nullifying" the Fifteenth Amendment, or failing to provide Negro equality under the Fourteenth in the South, it must be remembered that even a Constitution cannot break down the entrenched mores, and that the Court probably has done as much as it practically can to deal with local prejudice. Again, the Court has in general sought to avoid passing on the constitutionality of legislation, finding help in such devices as an excessively narrow conception of justiciability, the possibility of deciding the case on other grounds and holding tightly the procedural reins upon litigation. Although the Court has at times unwisely extended its power to invalidate legislation, it seems to be a fact that in at least $85 \%$ of the cases the legislation is sustained. On balance, therefore, there seems no justification for breaking down or materially, altering an institution which uniquely supplies that element essential to all governments and otherwise peculiarly lacking in the United States-stability and continuity.

This is not the place to enter into an historical examination of that remarkable phenomenon by which an individual or a group of individuals can challenge before a body of judges the validity of an Act of Government, of which those judges are a part. Perhaps the custom which permits this challenge to take place daily, almost unnoticed, is a symbol of the advance which the reign of law has achieved. But we have had

4. Cf. statistics in 2 Warren, Surreme Court in United Statfs History (1928) 741 ; Chief Justice Hughes in 16 A. B. A. J. 626, 629 (1930). 
occasion to learn in the last twenty years that no human institution is beyond destruction and that the hard-won victories of reaston wer force are especially vulnerable. Let us not, then, be unduly intuis rant of the Umpire, who, in time of stress and in time of tranquility, has had to hold in balance both the federal system and the respective clains of the individual and the community.

In that fluctuating struggle between individual and group for the recognition of their claims, we can read the social history of the country. As we know, the makers of the Constitution were jealous both of popular majorities and of governmental control. The times in which they lived and the Lockian philosophy in which they were nurtured made that seem natural. The Civil War, while centralizing governmental power, as does every war, also left in its wake renewed pledges to individual liberty and property, which were now placed under federal protection. And while the Slaughter-House case majority was unwilling to enlarge federal legislative or judicial power by reading a new content into the "privileges and immunities" clause of the Fourteenth Amendment, Field's view that the individual was now protected by the federal Government against the legislation of his own State finally won out through a gradual if extraordinary inflation of the innocent procedural phrase "due process of law". And this suited the Rugged Individualism of the Gay Nineties, when business expanded with the country. If thereby property values were stabilized and guaranteed against serious governmental impairment through the legerdemain of equating "due process" with "reasonable" laws and "just compensation", of transferring from the legislature to the judiciary the control over rates, ${ }^{6}$ of converting "personal liberty" into "freedom of contract" and "contract" into "property", ", of extending the

5. Railrozd Commission Cases, 116 U. S. 307 (1886); Chicago, Milmaukee \& St. Paul v. Minnesota, 134 U. S. 418 (1890).

6. Reagan v. Farmers Loan \& Trust Co., 154 U. S. 362 (1894).

7. Allgeyer v. Louisiana, 165 U. S. 578 (1897). It is unnecessary to invole the somewhat discredited "conspiracy theory" of the Fourteenth Amendment, to justify the Court"s extension of the protection of property to corporations. Cf. Graham, The Consfiracy Theory of the Fourteenth Amendment (1938) 47 Yare L. J. 371. Even if Roscoe Conkling misled the Court as to the contents of the Journal of the Congressional Committee. there is no conclusive evidence that his argument in the San 3 fateo case was the operative fact persuading the Court. Indeed, it does not matter whether the draftsmen had corporations in mind or not. We know that Bingham, the principal draftsman of the Amendment, thought that he had protected all persons, tiack and white, in the enjoyment of fundamental rights under the "privileges and immunities" clause; that he knew that "dur process" had before 1866 been used in a substantive sense to protect property. The Supreme Court invoked only normal powers of interpretation in including corporations within the term "persons." It would have been awkward to protect individual but nut carporate property against confiscation. Many clauses have been given an expansive interpretation which the draftsmen had not thought of. This does not impeach the propriety of the interpretation. It is not possible for the writer to agree with Justice Blacls's sensational attempt in Connecticut General Life Ins. Co. v. Johnson, 58 Sup. Ct. 436 (1938) to turn back the clock. 
immunities designed for the property-less Negro to the vast assets of that corporate "person" known as the Southern Pacific Railroad Company, ${ }^{8}$ it must be remembered that no great contemporaneous public protest was made. The record, with minor exceptions, ${ }^{0}$ does not disclose any vociferous tumult or even deprecating smiles when the New York Court of Appeals in 1885 held invalid a law prohibiting the manufacture of cigars in the tenement houses of New York and Brooklyn, embroidered with the following Individualist Manifesto:

"Such legislation may invade one class of rights to-day and another to-morrow, and if it can be sanctioned under the Constitution, while far removed in time we will not be far away in practical statesmanship from those ages when governmental prefects supervised the building of houses, the rearing of cattle, the sowing of seed, and the reaping of grain, and governmental ordinances regulated the movements and labor of artisans, the rate of wages, the price of food, the diet and clothing of the people, and a large range of other affairs long since in all civilized lands regarded as outside of governmental functions." 10

When, then, Justice Peckham in 1905 broke the camel's back with his interesting platitudes in Lochner $v$. New York, ${ }^{11}$ holding invalid as an interference with the freedom of contract a legislative limitation of ten hours daily labor in bakeshops, he cannot be said to have been out of the tradition of the founding fathers. Even when, a generation later, the United States Supreme Court held invalid a state law limiting the excess price that scalpers could charge on theater tickets; ${ }^{12}$ or a law providing for fixing wages and other terms of employment in labor disputes in certain essential industries, such as public utilities, food, fuel and clothing $;^{13}$ or limiting the fees to be charged by employment agencies ${ }^{14}$ or regulating the price of gasoline $;^{10}$ or making the sale of ice in Oklahoma a public utility, ${ }^{16}$ the majority probably believed that they

8. Santa Clara County v. Southern Pacific R.R., 118 U. S. 394 (1886).

9. One notable exception was Henry Carter Adams' monograph, Relation of the State to Industrial Action, Publications of the American Economic Ass'n, I, No. 6, 1887.

10. In re Jacobs, 98 N. Y. 98 (1885).

11. 198 U. S. 45 (1905).

12. Tyson v. Banton, 273 U. S. 418, 430 (1927) (by Sutherland, J.).

13. Charles Wolff Packing Co. v. Court of Industrial Relations, 262 U. S. 522 (by Taft, C. J.).

14. Ribnik v. McBride, 277 U. S. 350 (1928) (by Sutherland, J.). But see O'Gorman \& Young v. Hartford Fire Insurance Co., 282 U. S. 251 (1931) (sustaining a limitation on commissions of insurance brokers, by Brandeis, J.; dissenting opinion of Van Devanter, MicReynolds, Sutherland and Butler, JJ., on ground that the public had no interest in these agency contracts).

15. Williams v. Standard Oil Co., 278 U. S. 235 (1929) (by Sutlcrland, J.).

16. New State Ice Co. v. Licbmann, 285 U.S. 262 (1932) (by Sutherland, J.; dissenting opinion by Brandeis and Stone, JJ.). But the Court, by Sutherland, J., hal held 
constituted the bulwark of old-fashioned liberalism. When, however, in 1934 in the Nebbia case, ${ }^{17}$ it was discovered that there was no closed category of "business affected with a public interest" and that New York might through a Board fix the selling price of milk, laissez faire suffered a rude shock. To some, liberalism had changed its face. No longer the protector of the individual against social control, it had come to recognize that not only the interests of the community but parhaps the best protection for the individual lay in a reasonable limitation on the entrepreneur. All that had happened was that the humane liberals had prevailed over the fundamentalists-once the Lockian "Free enterprise" liberals, now the conservatives.

The reaction from Lochser v. New York gradually led to a new grouping of public opinion which sustained as necessary to the general welfare a certain amount, perhaps an ever greater degree, of state control. This movement, however deflected on occasion by decisions limiting the state's power to protect the social welfare by curtailing individual liberty, ${ }^{10}$ reached its culmination in a notable opinion of Chief Justice Hughes, speaking in 1934 for a bare majority of the Court, holding valid as not impairing the obligation of contract the Minnesota Mortgage Moratorium law extending the debtor's time for the redemption of the mortgage and limiting the rights of the mortgage creditor. ${ }^{10}$ The Chief Justice gave the reasons why more social organization was now necessary than heretofore and why, in his opinion, individual opportunity was thereby safeguarded rather than weakened. He said:

"It is manifest from this review of our decisions that there has been a growing appreciation of public needs and of the necessity of finding ground for a rational compromise between individual rights and public welfare. The settlement and consequent contraction of the public domain, the pressure of a constantly increasing density of population, the interrelation of the activities of our people and the complexity of our economic interests, have inevitably led to an in-

cotton ginning to be a "business affected with a public interest." Frost v. Corporation Commission, 278 U. S. 515 (1929).

17. Nebbia v. People of New York, 291 U. S. 502 (1934) (by Roberts, J.; dissenting opinion by McReynolds, Van Devanter, Sutherland and Butler).

18. Cf. Jones v. Securities \& Exchange Commission, 298 U. S. 1 (1936), in which Sutherland, J., defended the privilege of a registrant with the Securities and Exchange Commission to withdraw his application upon discovery of his misrepresentation. If this were denied, he said, the "cardinal precepts of personal liberty are violated;" the "Government ceases to be one of law and becoms an autocracy." Cardozo, J., dissenting, considers it a defense of business immorality in the name of personal liberty. Yet sometimes even criminals are protected in their civil liberties for public reasons. Cf. Nardone v. United States, 302 U. S. 379 (1937).

19. Home Building and Loan Association v. Blaisdell, 290 U. S. 398 (1934) (dissenting opinion by Sutherland, Van Devanter, McReynolds and Butler, JJ.). 
creased use of the organization of society in order to protect the very bases of individual opportunity." 20

A close case, which divided the Court last year, brings out the difference in attitude. Senn, a tile layer, worked for himself with an occasional helper or two. Not having been an apprentice, as the Tile Layers Union required, he could not be a member of the union; the union agreement also provided that only union members could install materials, and for that reason Senn declined to sign it. The union thereupon picketed Senn, as permitted by the Wisconsin labor code, as "unfair", and combined to prevent his getting jobs, on the justification that his non-union competition injured the union. The majority, speaking through Brandeis, $J$, held that the methods adopted by the union were not unlawful under the labor code, and that the Wisconsin law which thus assisted union labor was not in violation of the Fourteenth Amendment. ${ }^{21}$ The minority, speaking through Mr. Justice Butler, ${ }^{22}$ shocked at the statutory power thus indirectly to keep Senn from working as a tile-layer, invoked dramatically the inalienable privilege of the individual to engage in the common occupations of life, and the disability of the State to interfere with it. Butler quotes from Meyer v. Nebraska, prohibiting the State from interfering with instruction in a foreign language in a private school, as follows:

"While this Court has not attempted to define with exactness the liberty thus guaranteed, the term has received much consideration and some of the included things have been definitely stated. Without doubt, it denotes not merely freedom from bodily restraint but also the right of the individual to contract, to engage in any of the common occupations of life, to acquire useful knowledge, to marry, establish a home and bring up children, to worship God according to the dictates of his own conscience, and generally to enjoy those privileges long recognized at common law as essential to the orderly pursuit of happiness by free men." ${ }^{23}$

and from the somewhat notorious Coppage v. Kansas:

"Included in the right of personal liberty and the right of private property-partaking of the nature of each-is the right to make contracts for the acquisition of property. Chief among such contracts is that of personal employment by which labor and other services are exchanged for money or other forms of property. If this

20. Id. at 442 .

21. Senn v. Tile Layers Protective Union, 301 U. S. 468 (1937).

22. Id. at 483.

23. 262 U. S. 390,399 (1923) (by McReynolds, J.). These principles were enunciated by Bradley, J., in Butcher's Union Co. v. Crescent City Co., 111 U. S. 746,762 (1884) and first announced for a unanimous court in Allgeyer v. Louisiana, 165 U. S. 578 (1897). 
right be struck down or arbitrarily interfered with, there is a substantial impairment of liberty in the long-established constitutional sense. The right is as essential to the laborer as to the capitalist, to the poor as to the rich; for the vast majority of persons have no other honest way to begin to acquire property, save by working for money." 2s

After quoting similar generalizations, Justice Butler for himself and three colleagues expresses his conviction that the attempt to keep Senn out of a job was an unlawful purpose and that a law which permits it must be invalid. While the majority were probably familiar with the decisions and opinions quoted, they must have perceived a higher social interest in facilitating the unionization of all labor than the interest of Senn, personally. What is the higher interest in these matters is often a debatable question. Some of the considerations on which the Court seems to determine that question and the steps by which it achieved its position as umpire will now be examined.

\section{III.}

The processes and devices by which the courts arrogated to themselves the function of arbiter of social and economic policy exemplify the growth of constitutional law. We know that even before 1800 the courts read into the Constitution the so-called "inalienable" rights of the individual and constituted themselves the censors of much state legislation. All during the 19th century the process continued. They had to find appropriate phrases within which to clothe this extraordinary power and did so by invoking the "social compact", "natural justice", "law of nature", "common right", fundamental "spirit of the Constitution".25 Protest against this use of extra-judicial or unwritten criteria for exercising the veto power resulted in a successful effort to find terms within the written Constitution which would serve the same purpose, so that before the Fourteenth Amendment, the impairment of the obligation of contracts clause, and in the states "law of the land" were often invoked as limitations on legislative interference with rights in property and other personal privileges.

24. 236 U. S. 1, 14 (1915). Cf. Hughes, C. J., in West Coast Hotel Co. v. Parrish, 300 U. S. 379,391 (1937) : "But the liberty safeguarded is liberty in a social organization which requires the protection of law against the evils which menace the bealth, safety, morals and welfare of the people."

25. Cf. Chase, J., in Calder v. Bull, 3 Dall. 386 (U. S. 1798) ; Story, J., in Terrett v. Taylor, 9 Cranch 43 (U.S. 1815) ("standing upon the principles of international jus. tice, upon the fundamental laws of every free government, upon the spirit and letter of the constitution"). Howe, The Mfeaning of "Duc Process of Law" Prior to the Adoption of the Fourteenth Amendment (1930) 18 CALIF. L. REv. 583; Corvin, The "Higher Lou" Backgrousd of American Constitutional Low (1928) 42 HABv. L. REv. 149; Grant, The Natural Laze Background of Due Process (1931) 31 CoL L. Rev. 56. 
This function of enabling judges by the process of interpretation to write their own Constitutional limitations upon legislative power was accompanied by the view that the legislative power of the states was a limited power, a grant of specific powers; and although that view conflicts with theory, in fact the grant of powers to the legislature has been construed as a limitation. Had Chase, $J$, in Calder v. Bull, perhaps with justifiable prescience, not taken the heart out of the ex post facto clause by limiting it to criminal legislation, we should have seen an even wider judicial control over the legislature in the invalidation of "retroactive" legislation diminishing vested rights.

Even before the due process clause was timidly invoked in New York, ${ }^{20}$ the theory that the judges' view of public policy could define both the unwritten and the written limitations on legislative power was entrenched. The belief that the due process clause related only to procedure doubtless prevented its wider use, but in the Dred Scott case it found its way as a substantive limitation into the United States Supreme Court. ${ }^{27}$ The function of judicial control was further aided by the court's ability to interpret the other element in the equation, "property" and later "liberty". The abstraction property was extended by several courts, even before the Fourteenth Amendment, to include various types of intangible rights, franchises, remedies, contracts, the privilege of engaging in trade, the right to use property in certain ways. Even the term police power had come into use, with the courts the judges of the question whether the invasion of private property or liberty was adequately justified on public grounds. If not, the courts had innumerable catchwords to draw upon to justify the disallowance. The Fourteenth Amendment merely gave the federal courts a specific power to assume a jurisdiction that they had already exercised to a limited extent, provided the state legislation offended the judges' innermost convictions. Those convictions still rule the process of interpretation, but they have as we know experienced the same metamorphosis that in general public opinion has undergone, namely, from skepticism to toleration of public control, with the special facts determining the balance of power in any given case.

But as we know, the potentialities of the "due process" clause after 1868 as a means of censoring state legislation, to which function even Field expressed repugnance, were not at once recognized, because the judicial power to protect private rights against encroachment was regarded as adequately safeguarded by the "privileges and immunities" clause of the first section of the Fourteenth Amendment. Field, Bradley and Peckham showed the way, for of Miller's opinion in the Slaughter-House

26. Taylor v. Porter, 4 Hill 140 (N. Y. 1843); Wynehamer v. State of New York, 13 N. Y. 378 (1856).

27. See Taney, C. J., in Dred Scott v. Sanford, 19 How. 393, 450 (U. S. 1856). 
cases ${ }^{28}$ only that part has remained in practical effect which inferentially -and in the Civil Rights cases expressly ${ }^{20}$-prohibits Congress from legislating directly to impose on individuals the obligatiun of equal treatment to the Negro and similar victims of discrimination.

Miller's view that the "privileges and immunities" covered only the privileges of federal citizenship against state impairment, requiring as it did an involved distinction between state and federal privileges and a practical emasculation of the clause, resulted in obliging other judges of the Court to read all kinds of limitations into the "due process" clause of the Amendment. It is doubtful whether Miller's narrow and indeed nullifying construction of the "privileges and immunities" clause represented good statesmanship. His view was actuated by the fear, fortified by the Civil Rights Act of 1866, that Congress would, under the fifth section of the Fourteenth Amendment, assume to legislate all the civil rights of the individual throughout the states and thus transfer to the federal government, as others have remarked, the entire police power.

But this was not a necessary consequence of giving the "privileges and immunities" clause the meaning originally intended by its draftsmen, namely, to safeguard against state impairment the bill of rights of the first eight Amendments. It would still have been possible to limit the scope of the fifth section ${ }^{30}$ to the bounds of corrective or penalty legislation upon the states which violated the injunctions of the "privileges and immunities" and due process and equal protection clauses, as was later held in the Civil Rights cases. ${ }^{31}$ Although Miller's distinction between state and federal citizenship has been affirmed by the Court in later decisions, its significance is breaking down through the broad interpretation now given to the word "liberty" of the Fourteenth Amendment and through the doubts cast upon its impregnability by Colgate a. Hari'y," in which it was held to be a privilege of a citizen of the United States not to be taxed by Vermont at a higher rate for investing money outside than inside the state. There would be far greater advantage in restoring the original meaning of the "privileges and immunities" clause and by the process of inclusion and exclusion letting the country know what are now federal privileges, than in forcing the court to draw upon the fathomless depths of the "due process" clause to give effect to their personal convictions of economic and social propriety.

The process of constitutional evolution has thus brought it about that the main purpose of the Fourteenth Amendment (equal protection for

28. Slaughter-House Cases, 16 Wall 36 (U. S. 1873).

29. 109 U. S. 3 (1883).

30. "The Congress shall have power to enforce, by appropriate legisiation, the provisions of this Article."

31. Supra, note 29.

32. 296 U. S. 404 (1935). 
the Negro) has been largely frustrated, whereas a function then not thought of, the protection of private property against the police power, has become perhaps the most striking feature of the Amendment. And the protector is the Supreme Court itself. In a series of pronouncements commencing with the dissenting or concurring opinions of Field and Bradley in the Slanghter-House, Bartemeyer, Munn and Crescent City cases $^{33}$ and reaching unanimous approval with Peckham's opinion in the Allgeyer case, ${ }^{34}$ that Court made itself the judge of the issue whether legislation restricting private rights was or was not an undue encroachment. The question will remain whether this expansion of judicial power has done the country more harm than good. For it must be remembered that, aside from the stabilization of property values, the extraordinary enlargement of the concept "liberty" first announced in the Allgeyer case, was later employed-with widespread approval-to enable the Supreme Court to pass upon state violations of civil liberties, such as the freedom of speech, press and assembly.

We are informed by learned judges that the obligation to declare legislation unconstitutional is inexorable. The Constitution necessarily must prevail. Thus, we are told, it was discovered by the simple process of laying the Constitution beside the statute that minimum wage requirements for women ${ }^{35}$ were unconstitutional and that agriculture was a local industry, hence incapable of federal subsidy by processing taxes in return for agreed restriction on production. ${ }^{36}$ Yet we have also been told that statutes and the Constitution mean what the judges say they mean. ${ }^{87}$ And this must be so; for we can trace in the fifty-year period between 1886 and the present day the steady expansion of judicial review and the frequent substitution of the Court's own views of social policy for those of the legislature. If the majority of the Court approves the law and the policy it is constitutional; if it does not, it is unconstitutional. The Lochner case, ${ }^{38}$ in 1905 marks the highpoint of what is now called the conservative view. With the ascendant influence of Holmes and Pitney, the Court later accepted on the whole the Progressive view of social policy and sustained labor legisiation for the protection of women and, in the Bunting case, ${ }^{39}$ even of men, and after 1914 , a wide range

33. See dissents in Slaughter-House cases, 16 Wall. 36, 83 (U. S. 1873); dissent in Munn v. Illinois, 94 U.S. 113, 136 (1877) (by Field and Strong); concurring opinions of Field and Bradley in Bartemeyer v. Iowa, 18 Wall. 129 (U. S. 1873) and in Butchers Union v. Crescent City Co., supra note 23. People v. Burd, 117 N. Y. 1 (1889), following the doctrine of Munn v. Illinois, and dissents by Peckham and Gray.

34. 165 U. S. 578 (1897).

35. Adkins v. Children's Hospital, 261 U. S. 525, 544 (1923).

36. United States v. Butler, 297 U. S. 1, 62 (1936).

37. Cf. Hughes, The Supreare Court of the United States (1938) 41, 230.

38. 198 U. S. 45 (1905).

39. Bunting v. Oregon, 243 U. S. 426 (1917). 
of workmen's compensation legislation and state socialization. ${ }^{40}$ W'ith the War came a climate of reaction, evidenced not only in free speech cases but in other cases as well."1 The post-war fear of radicalism then induced in certain judges, occasionally making a majority, a renewed opposition to social control. During the 1920's price-fixing and other police power measures were not infrequently invalidated.2 Since the depression, a sounder view of the necessity of broadening the scope of legislative discretion in regulating the community's economic and social relations has with certain exceptions, achieved support, until even the notorious minimum wage policy, over the grieved protest of Justice Sutherland and his conservative colleagues, has after fifteen years been

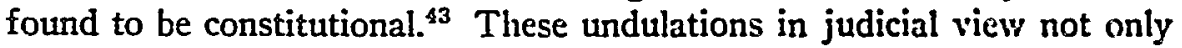
reveal the true source of constitutional authority and the utility of keeping it abreast of the-times, but also the importance of judicial self-restraint in employing the power to pass upon social questions.

The road by which the Supreme Court achieved judicial supremacy in the social field has been pointed out by several writers. ${ }^{48}$ After the Murn case, the Court ultimately accepted as law the reiterated dissents of Field and Bradley, a feat accomplished through the mediation largely of Justice Peckham, who brought with him from the New York Court of Appeals certain doctrines there nurtured as fundamental truths. The Court of Appeals in the. Jacobs casc, already referred to, assumed that it, rather than the legislature, was the judge of the question whether the police power was properly used, i.e., whether the evil to be cured or the object to be achieved was within the scope of the police power and whether the method employed was "convenient" or "appropriate" to the end in view. What license the courts had to undertake that function no one explained, and as already observed, in a period of rampant individualism, the view was not unwelcome to those with economic stakes in the community. Even Justice Miller, who in the Slanghter-House cases had rejected the notion that the Supreme Court could be made the censor of all state legislation, remarked in Loan Association z'. Topeka, an eight to one decision, that "it must be conceded that there are . . . rights in every free Government beyond the control of the State." The limitations on the power of the State, thought Miller, grew "out of the essential

40. Cf. Green v. Frazier, 253 U. S. 233 (1920).

41. Cf. United States v. Chemical Foundation, 272 U. S. 1 (1926).

42. Compare Block v. Hirsch, 256 U. S. 135 (1921), where a rent restriction law in an emergency was sustained, with Chastleton Corporation v. Sinclair, 264 U. S. 543 (1924), where it was not sustained, because the emergency was deemed to have passed.

43. West Coast Hotel Co. v. Parrish, 300 U. S. 379 (1937).

44. See Boudin, Governutent by Judiciary (1932, 2 v.); Charles Warren, The vety "Liberty" under the Fourteenth Amendment (1926) 39 HARv. L. REv. 431, 437; Corwin, The Fourteenth Amendment (1909) 7 MICr. L. Rev. 643.

45. 20 Wall. 655 (U. S. 1874). 
nature of all free governments, implied reservations of individual rights, without which the social compact could not exist . .."46 A government which recognized no such rights, he said, was a "despotism". Justice Clifford, the lone dissenter, took more earnestly the denial that the Court had any but expressly declared supervisory power over the legislature, for, he said, the "courts are not the guardians of the rights of the people of the State, save where those rights are secured by some constitutional provision which comes within judicial cognizance . . ." otherwise the courts would become sovereign and "convert the government into a judicial despotism." 47

Thus the two contrasting views of judicial power were definitely established. Which view prevailed we now know; but the victors have not in recent years led a happy life. Always their citadel has been under attack, recently to the point of threatening the integrity of the Court. The power nevertheless developed naturally, because it was merely an extension of already conceded functions. Only when the police power began to place restrictions on the use of private property and on the exercise of individual activity did the supervisory function of the Court expand, and by that time its friends and the climate of opinion had conspired to permit its relatively unhampered development. Indeed some of the judges today regard the power as a "vested right" and resent as nearly preposterous the suggestion that it should be exercised with restraint. ${ }^{48}$ These objecting judges believe that they expound the Constitution, not their own views. They would deny the validity of the opinion expressed nearly sixty years ago by Justice Holmes in his book on the Common Law that every legal principle is the expression of the judges' public policy, a result of "instinctive preferences and inarticulate convictions." If this is true of the common law, how much more true is it of governmental doctrine.

We have alluded to the devices employed by the courts to arrogate to themselves this immense power of finally passing on social legislation. This was done in the Jacobs case ${ }^{4 \theta}$ by questioning the integrity of the legislative use of the police power. On the assumption that the police power had only a limited scope, the courts would argue that the statute merely pretended to be a police power measure, that in fact it had no police power purpose, or that if ostensibly passed for such a purpose, e.g., health, that the means employed had no relation to that end or were not calculated to promote it. This line of reasoning, charging the legislature with disingenuousness or ineptitude, throttled much legislation

46. $I d .$, at 663 .

47. Id., at 668-669.

48. Cf. Justice Sutherland's protest of this view in West Coast Hotel Co. v. Parrish, 300 U. S. 379 (1937).

49. 98 N. Y. 98 (1885). 
which today is accepted as indispensable. The reasoning, or rather the major premise which dictated the result, served for a time to undo statutes for the limitation of hours, workmen's compensation, union labor protection, prohibition of child labor, and minimum wages. ${ }^{* 0}$ In People $v$. $B$ sodd, ${ }^{51}$ the majority of the New York court believed public opinion was a sufficient restraint upon excessive legislative invasions of private liberty or property, but the dissenters, led by Peckham, thought that state control of grain elevators' charges was a reversion to the paternalistic government of the 17 th or 18 th century. The "liberty" which the majority undertook to protect against state invasion in the Allgeyer case was
"deemed to embrace the right of the citizen to be free in the enjoy- ment of all his faculties, to be free to use them in all lawiul ways; to live and work where he will; to earn his livelihood by any lawful calling; to pursue any livelihood or avocation, and for that purpose to enter into all contracts which may be proper, necessary and es- sential to his carrying out to a successful conclusion the purposes above mentioned."

It seems churlish to question this benevolent language; and yet in subsequent years restraints upon the liberties mentioned have had to be exerted and have been sustained. The NRA even contemplated governmental licenses to enter overfilled occupations, and if necessary, prohibiting entrance The freedom of contract has been seriously limited. ${ }^{63}$ Indeed, practically the same conservative court which pronounced the Lochner decision had a few years earlier recognized that inequality in bargaining power constituted a justification for the state's limitation of hours of labor in dangerous occupations; ${ }^{64}$ soon thereafter came a recognition that differences in physical capacity between men and women justified a differentiation in working conditions ${ }^{55}$ that the state had an interest in the health of all its workers, and could prevent them from being employed

50. Cf. Lochner v. New York, 198 U. S. 45 (1905); Ives v. So. Buffalo Ry., 201 N. Y. 271,94 N.E. 431 (1911); Adkins v. Children's Hospital, 261 U. S. 525 (1923); Adair v, United States, 208 U.S. 161 (1908); Hammer v. Dagenhart, 247 U.S. 251 (1918).

51. 117 N. Y. 1 (1889).

52. Allgeyer v. Louisiana, 165 U. S. 578, 589 (1897). Cf. the language of the Court which struck down the District of Columbia minimum wage law in 1922: "To sustain the individual freedom of action contemplated by the Constitution, (to work for any low wage) is not to strike down the common good but to exalt it; for surely the good of society as a whole cannot be better served than by the preservation against arbitrary restraint of the liberties of its constituent members." 261 U. S. 525, 561.

53. Cf. Chicago, B. \& Q. Ry. v. MfGuire, 219 U.S. 549, 567 (1911); West Coast Hotel Co. v. Parrish, 300 U. S. 379 (1937).

54. Holden v. Hardy, 169 U. S. 366 (1898). Cf. AIcLean v. Arlansas, 211 U. S. 539 (1909); West Coast Hotel Co. v. Parrish, 300 U. S. 379 (1937).

55. Muller v. Oregon, 208 U. S. 412 (1908). 
over ten hours a day in a manufacturing establishment, ${ }^{56}$ until now not only wage and hour statutes but many other provisions for the protection of labor are deemed valid. ${ }^{57}$ The vaunted liberty of contract has suffered many restraints, not because liberty is no longer held in esteem but because its exposure to abuse resulted in constraint of the weaker and because a wider general liberty is often better achieved by restriction or regulation of what had become license. Now we find in ever-greater degree the interstate commerce and the taxing powers employed for police power purposes. ${ }^{68}$ So liberal to labor legislation had the Supreme Court become after 1908 , as contrasted with the restrictive views of the state courts, that labor itself in 1913 demanded an appeal by certiorari to the Supreme Court from state decisions holding state legislation unconstitutional on federal grounds. ${ }^{59}$

The Court's power to do what it wishes and to carry into the decision an inarticulate major premise is aided or accompanied by certain contrivances. One of these is to begin from an alleged presumption of constitutionality. If the statute is sustained, the obeisance to the legislature is usually brief. ${ }^{60}$ The more questionable the propriety of the decapitation about to be committed the more fervent the attendant profession of devotion to and respect for the legislative will. Thus, the Adkins minimum wage opinion begins with the familiar ritual: "The judicial duty of passing upon the constitutionality of an act of Congress is one of great gravity and delicacy. The statute here in question has successfully borne the scrutiny of the legislative branch of the Government which, by enacting it, has affirmed its validity; and that determination must be given great weight." No case more fully justified genuine adherence to this view. But when the court has decided on annihilation of the statute, it is surprising how easily "clear and indubitable demonstration" can overcome the presumption of validity. ${ }^{\text {1 }}$

The actuating postulates of the Court may be quite tenacious, however, and it is these postulates which usually decide the case. Where the Court is willing to take judicial notice of the propriety of the restraint on private rights, it will either rely on the legislative findings, or presume a condition of fact justifying the regulation, or decline to accept evidence show-

56. Bunting v. Oregon, 243 U. S. 426 (1917).

57. Cf. The Social Security Act, sustained in Steward Machine Co. v. Davis, 301 U. S. 548 (1937).

58. Cf. Santa Cruz Fruit Packing Co. v. National Labor Relations Board, decided March 28, 1938, 58 Sup. Ct. 656; Magnano Co. v. Hamilton, 292 U. S. 40 (1934).

59. Act of March 23, 1914, 38 Stat. 790, 28 U. S. C. $\$ 344$ (b) (1934).

60. O'Gorman \& Young v. Hartford Fire Insurance Co., 282 U. S. 251 (1931); South Carolina State Highway Dept. v. Barnwell Bros., 58 Sup. Ct. 510, 519 (1938). But cf. Borden's Farm Products Co. v. Baldwin, 293 U. S. 194 (1934).

61. 261 U. S. 525, 544 (1923). 
ing the inequitable operation of the statute in a particular case. ${ }^{02}$ On the other hand, where the Court starts from the presumption that the legislation, as in the Lochner case, is a "meddlesome interference with the rights of the individual," or that "liberty is the rule and restraint the exception," ${ }^{83}$ it will probably disregard the legislative finding and demand an exceptional preponderance of evidence of constitutional facts from the supporter of the legislation. ${ }^{\text {s }}$ The greater the degree of prejudice or preconception, the greater the burden to overcome it. Hence the growing science of pleading constitutional facts and the Court Rule that when constitutional facts are incapable of judicial notice the lower courts shall make findings of fact.

In administrative proceedings the Court has reserved a supervisory control of findings of fact, which has again enabled it to do what it wishes to do. It is really bound by few precedents. Perhaps this flexibility is desirable, but the rationalization for both adhering to and departing from previous decisions is not always satisfying.

The Court's solicitude for private interests is evidenced in the control exercised not only over the method of reaching administrative findings, but over the findings themselves. Especially where rate-making and hence "confiscation" is involved, the Court is disposed to review administrative findings. Thus, in the recent St. Joseph Stockyards case, the Chief Justice remarked: "Legislative agencies . . . work in a field peculiarly exposed to political demands . . . But to say that their findings of fact may be made conclusive where constitutional rights of liberty and property are involved . . . is to place those rights at the mercy of administrative officials and seriously to impair the security inherent in our judicial safeguards."

And yet, even here a change is noticeable. A distinction is being recognized between the different types of administrative agencies and hence between the varying need of judicial review. The more expert the administrative agency, to which of necessity an ever greater degree of control over private right must be relegated, the less disposed are the courts to

62. Lindsley v. Natural Carbonic Gas Co., 220 U. S. 61, 78 (1911); Rast v. Van Deman \& Lewis Co., 240 U. S. 342, 357, 370 (1916) ; Borden's Farm Products Co. v. Baldwin, 293 U. S. 194 (1934); cf. Powell v. Pennsylvania, 127 U. S. 678 (1835); Ex parte Kair, 28 Nev. 127, 80 Pac. 463 (1905).

63. Adkins v. Children's Hospital, 261 U. S. 525 (1923).

64. Cf. Liggett v. Baldridge, 278 U. S. 105, 111 (1928) (no relation found between stock ownership and public health in statute requiring drug stores to be owned by pharmacists).

65. Equity Rule 70-1/2. See the valuable note in (1931) 49 HAns. L. REv. 631. Cf. Burns Baking Co. v. Bryan, 264 U. S. 504, 44 Sup. Ct. 412 (1924) (the Court made its own finding that tolerance for shrinkage in the statutory weight of losves of bread was inadequate). See also Weaver v. Palmer Bros., 270 U.S. 402 (1926).

66. St. Joseph Stockyards Co. v. United States, 298 U. S. 38, 52. 
review their findings of fact. Even the reservation to the Supreme Court of control of jurisdictional or "constitutional" facts ${ }^{67}$ is meeting with growing opposition as an unnecessary obstruction of the administrative process. The courts have probably burdened themselves unduly in reviewing valuation for rate-making purposes, where they might well limit judicial control, especially of state commissions and courts, to the dispensing of substantial justice. Such a case as McCart $v$. Indianapolis Water Co., ${ }^{88}$ representing a continuous shuttling from commission to courts and back again without visible end, might well be cut off, as Justice Black suggested, by a refusal to review that vast collection of fluctuating hypotheses which Smyth $v$. 'Ames ${ }^{89}$ dictated as factors in rate-making, whenever the Court considers substantial justice to have been done to the utility as well as to the consumer. The opportunity to review procedure and to set aside findings that have no or inadequate support in the evidence gives the Court full control over arbitrariness or gross injustice. Perhaps Texas has found the answer, at least in part. To meet the argument that a utility is entitled to an independent judicial judgment upon the facts and the law, Texas provided that a state court jury would pass on the evidence, de novo, if desired, and the Supreme Court has considered that this satisfied the requirement of due process, and, while not conclusive, the finding is apparently entitled to greater weight than a commission finding. ${ }^{70}$

Perhaps the principal way by which the Supreme Court has become the final judge of social policies and brought upon itself the appellation of "a third legislative body" is by disregarding the natural limitations upon the judicial function. Years ago Holmes, and in more recent times Brandeis, Stone and others, have admonished the judges of the Court against undertaking to vote on legislation as if they were members of the legislature. They have been urged not to read their own economic predilections into the due process clause. Yet only a few of the judges have apparently been able to make Holmes' distinction between the attitude of a judge and that of a legislator. Only when the judge can say that no reasonable body of men sitting in a legislature could have thought that an evil existed or that the method adopted was conducive

67. Ohio Valley Water Co. v. Ben Avon Borough, 253 U. S. 287 (1920) (evidence for public utility valuation); Crowell v. Benson, 285 U.S. 22 (1932) (place of injury as affecting jurisdiction under Harbor Workers' Compensation Act); Baltimore \& Ohio R.R. v. United States, 298 U. S. 349 (1936) (rates as fair return) ; cf. Oppenheimer, The Supreme Court and Administrative Law (1937) 37 CoL. L. Rev. 1.

68. 302 U.S. 419 (1938). Perhaps Railroad Commission v. Pacific G. \& E. Co. 58 Sup. Ct. 334 (1938) indicates that valuation will no longer be subjected to supposedly rigid tests. Cf. review of the cases in note, Judicial Control Over Methods of Valuation in Public Utility Rate Cases (1938) 51 HaRv. L. Rev. 885.

69. 169 U. S. 466 (1898).

70. United Gas Public Service Co. v. Texas, 58 Sup. Ct. 483 (1938). 
toward its eradication, or that the legislation is "utterly unreasonable and extravagant" 71 is the Court justified-pretermitting the propriety of the substantive conception of due process ${ }^{72}$-in refusing to uphold it. On occasion the Court has avowed such a policy. It has said:

"The mere fact that a Court may differ with the legislature in its views of public policy, or that judges may hold views inconsistent with the propriety of the legislation in question, affords no ground for judicial interference..."73

That is what Justice Stone doubtless meant by a sense of judicial selfrestraint.

IV.

What are the private rights which the Supreme Court has protected? We can perhaps say that they have no established and permanent content, for they depend on that changing polity which necessarily affects the views of the Court at any particular time. ${ }^{74}$ The emasculation of the "privileges and immunities" clause of the Fourteenth Amendment left under precarious State protection most of the guaranties embodied in the Bill of Rights, although it was doubtless the purpose of the framers of that clause to place those guaranties under federal control. Limited further by the narrow construction given to the legislative power of Congress under the fifth section of the Fourteenth Amendment, and the broad leeway to practical inequality which the "equal protection" clause affords, Negro and other minorities can hardly find much satisfaction in the enlargement of individual freedom and legal equality which the -Amendment was supposed to assure.

Criminal jury trial and the writ of habeas corpus in the states, though considered so fundamental as to be embodied in the text of the original constitution, may now be cut down, if not indeed abolished. Religious freedom, perhaps the freedom of assemblage, the suffrage within slight

71. MicLean v. Arkansas, 211 U. S. 539 (1909).

72. Brandeis, J., admitted in Whitney v. California, 274 U. S. 357, 373 (1937) that the application of due process to substantive law was "settled." But for that view, many civil liberties would be without federal protection.

73. Ibid. Cf. Hughes, C. J., in West Coast Hotel Co. v. Parrish, 300 U. S. 379, 399 ("Legislative response to that conviction cannot be regarded as arbitrary or copricious, and that is all we have to decide. Even if the visdom of the policy be regarded as debatable and its effects uncertain, still the legislature is entitled to its judgment") The question is "whether it is possible to say that the legislative choice is without rational basis." South Carolina State Highway Dept. v. Barnwell Bros., 53 Sup. Ct. 510, 517 (1938).

74. Cf. The rent restriction cases, supra note 42. In Powell v. Pennsylvania, 127 U. S. 678 (1888), the Court tolerated legislative suppression of an industry. In Mtagnano v. Hamilton, 292 U. S. 40 (1934), a unanimous court, by Sutherland, J., permitted such a result by use of the taxing power. 
limitations, cultural rights, are hardly under federal protection. While the expanded conception of "liberty" has brought under federal supervision certain state invasions of what are deemed indispensable or fundamental personal privileges, ${ }^{75}$ the great assaults have come from private sources which the State is unwilling to control; and the Supreme Court unfortunately seems to consider state inaction as not subject to the same judicial sanctions as state action. ${ }^{76}$ Perhaps some day a broader view of the protective function of the Fourteenth Amendment will be taken.

In time of stress, also, when the guaranties of the bill of rights are most needed, they are likely to be tacitly suspended. The protection afforded by the avowals in Ex parte Milligan ${ }^{77}$ were practically unavailable during the Great War. In the hysteria about labor and revolutionary trouble after the War, some of the most drastic statutory assaults on freedom of speech and assembly escaped federal censure, under the rationalization that the changes in the social or political order contemplated by radical groups could not be accomplished except "by force and violence". The "clear and present danger" that advocacy might ripen into action, the jury test which the Court laid down in the Schenck case ${ }^{78}$ has been of little help in time of public excitement. ${ }^{79}$ Pacifism may be preached only when there is no danger of war and most safely at luncheons of the Foreign Policy Association.

But the Supreme Court has gone further in approving restrictions on political expression. In the Gitlow case ${ }^{80}$ a distributor of the Left Wing

75. This by no means includes all the privileges mentioned in the first eight amendments. A good review of the dividing line between the privileges of fundamental importance, protected by the Fourteenth Amendment, and those of secondary importance, not so protected, will be found in Palko v. Connecticut, 302 U. S. 319 (1938) (by Cardozo, J.).

76. The Supreme Court has not really passed on the question. Inferences in cither direction can be drawn. Cf. Truax v. Corrigan, 257 U. S. 312 (1921) (injunction denied); Powell v. Alabama, 287. U. S. 45 (1932) (failure to allow counsel). The view of Congress is declared in the Civil Rights Art, to the effect that if the "constituted authorities" of any state "shall be unable to protect or shall for any cause fail in or refuse protection of the people in such rights, such facts shall be deemed a denial by such state of the equal protection of the laws." The same principle is embraced in the federal anti-lynching bill. See Legis. (1938) 38 CoL. L. REv. 199; (1933) 33 CoL. L. REv. 854. Logically, a "denial" of equal protection is just as possible by inaction (negligence, failure to act) as by action. International law holds the State responsible in both cases.

77. \& Wall. 2 (U.S. 1866). On this general subject, see Boudin, The Suspreme Court and Civil Rights, 1 Science and Society (1937) (No. 3) 273; Fraenkel, The Supreme Court and Civil Liberties, American Civil Liberties Union (1937); Donovan, An Independent Supreme Court and the Protection of Minority Rights (1937) 23 A. B. A. J. 254.

78. 249 U. S. 47 (1919).

79. Cf. Abrams v. United States, 250 U. S. 616 (1919) (Abrams and others drew sentences of twenty years for issuing pamphlets condemning American intervention against Soviet Russia). See also Pierce v. United States, 252 U. S. 239 (1920) (punishment for publishing a pamphlet stating some of the factors which produced American entry into the war). Gilbert v. Minnesota, 254 U. S. 325 (1920).

80. 268 U. S. 652 (1925). 
Manifesto, representing a group of insignificant radicals, was convicted under a New York criminal anarchy statute not because there was any "clear and present danger" that anybody would be converted by his declamation but because the State in its own protection could stop the advocacy of doctrines which the Court construes as contemplating violence. Mriss Whitney was dealt with even more harshly. She merely associated with those who were organizing the Communist Labor Party, which was said to be advocating violent revolution. ${ }^{81}$ That looks as if mere membership in the Party might be held punishable, as it is in some states, although the Supreme Court has not yet so held. Probably undue significance is attached to the reversal of a criminal conviction of a communist in Oregon, De Jonge, ${ }^{82}$ on the ground that although he presided over a meeting of communists, he was engaged in protesting illegal action of the police in permitting a strike meeting to be broken up, and was not preaching communism. Had he been, he might have been in the toils. ${ }^{83}$ Even Herndon, ${ }^{88}$ young Negro communist from Georgia, convicted under an old "insurrection" statute, finally escaped serving sentence because the evidence did not show that he had distributed communistic literature or preached the faith. It is to be welcomed that the "clear and present danger" test has been revived in the Herndon case, i.e., in criminal syndicalism cases, as against the "dangerous tendency" test of the Gitlow case.

When the Court finds a particular conviction too nauseating, it is likely to discover in the record some ground on which the conviction can be reversed. So, the California statute prohibiting the display of the red flag was too much even for Justice Butler. ${ }^{85}$ In the dilemma which the advocacy of radical doctrines has furnished, the Court is perhaps vise just now in deciding each case on narrow grounds, however unsatisfactory that may be. When the climate of opinion is hostile to industrial change or to the Jeffersonian doctrine of frequent political change, it is well not to ask for general commitments. The present Court is likely to establish a reasonable balance between free political expression and the preservation of the safety of the State. On the whole, therefore, one can reach his own conclusions as to whether the freedom to utter unwelcome doctrine has been safeguarded by the Supreme Court.

The freedom of the press, now also brought under the protection of the Fourteenth Amendment, has received support from the Court by prohibiting both advance censorship of a scandal sheet and indirect

81. Whitney v. California, 274 U. S. 357 (1927).

82. De Jonge v. Oregon, 299 U. S. 353 (1937).

83. The Circuit Court of Appeals for the fifth Circuit is reported to have held recently that membership in the Communist Party was not a sufficient ground for deportation.

84. Herndon v. Lowry, 301 U. S. 242 (1937).

85. Stromberg v. California, 283 U. S. 359 (1931). 
methods of controlling editorial expression. ${ }^{86}$ But during the War drastic restrictions by administrative order were sustained, ${ }^{87}$ so that while it is still possible to criticize the Government in time of public tranquillity, it is doubtful how far that privilege will be sustained in time of stress.

The Supreme Court has not considered itself justified in insuring the administration of justice in the States. Even a "fair trial" has not been deemed the court's special concern. But in recent years some relaxation of their hesitancy to intervene is apparent, and when the procedure is too outrageous, the Court has assumed jurisdiction. Thus, mob domination of the trial, a prosecutor's participation in perjury, the denial of counsel, a forced confession, have been deemed violations of federal due process. ${ }^{88}$ So when flagrant miscarriages of justice occur in state courts. As time goes on, we are likely to find an ever greater disposition to impose the principal guaranties of the bill of rights upon the states, if not under the "privileges and immunities" clause, then under the due process and equal protection clauses. ${ }^{8 \theta}$ To that end, a relaxation of the requirements to become a "person within the jurisdiction" is noticeable. ${ }^{\text {co. }}$

To that noble experiment, Prohibition, we owe much of our knowledge concerning the guaranty against unreasonable searches and seizures. Without reviewing the cases it may be said that the Court has placed severe restrictions upon the methods by which evidence may be obtained and thus has placed a pretty effective check on lawlessness by enforcing officers. $^{01}$ While this has annoyed many judges, on the ground that the immunity has been invoked by criminals and has hampered the enforcement of the law, the Court has recently defended its rule, ${ }^{02}$ in a case prohibiting wiretapping as a means of securing evidence, by the view that "Congress may have thought it less important that some offenders should go unwhipped of justice than that officers should resort to methods

86. Near v. Minnesota, 283 U. S. 697 (1931); Grosjean v. American Press Co., 297 U. S. 233 (1936) ; Lovell v. City of Griffin, Ga., 58 Sup. Ct. 666 (1938) (no broad license fermitted as condition of distributing handbills or religious tracts).

87. United States ex rel. Milwaukee Publishing Co. v. Burleson, 255 U. S. 407 (1921).

88. In Frank v. Mangum, 237 U. S. 309 (1915), mob domination was not deemed adequate grounds for due process jurisdiction. But in Moore v. Dempsey, 261 U. S. 86 (1923) it was. See also Mooney v. Holohan, 294 U. S. 103 (1935) (perjury); Powell v. Alabama, 287 U. S. 45 (1932) (denial of counsel); Brown v. Mississippi, 297 U. S. 278 (1936) (third degree).

89. Cf. Norris v. Alabama, 294 U. S. 587 (1935) (systematic exclusion of Negroes from grand juries by administrative officers); Patterson v. Alabama, 294 U. S. 600 (1935) ; Buchanan v. Warley, 245 U. S. 60 (1917) (land ownership).

90. Compare Southern Ry. Co. v. Greene, 216 U. S. 400 (1910) with Power Mfg. Co. v. Saunders, 274 U. S. 490 (1927).

91. Cf. Gouled v. United States, 255 U. S. 298 (1921); Gambino v. United States, 275 U. S. 310 (1927).

92. Nardone v. United States, 302 U. S. 379 (1937), overruling Olmstead v. United States, 277 U. S. 438 (1928). 
deemed inconsistent with ethical standards and destructive of personal liberty." Even though this may seem to the dissenters an "overflow of sentimentality", it counterbalances the natural tendency of the State and its administrators to consider themselves above the law.

In labor relations the Court has displayed a progressive tendency to sustain statutes which give advantages to the laborer in his dealing with the employer. Many police power measures necessarily have as their purpose the redress of a disequilibrium in the relations between persons and groups by throwing the mantle of legal protection about those who are handicapped. Notwithstanding the nineteenth century failure to appreciate this necessity and its insistence on the freedom of contract as the key to labor relations, the twentieth century, with minor exceptions, has witnessed a disposition to support enlargements of the laborer's privileges. In recent years, when federal power has been so widely extended, this tendency has been manifested even to the extent of broadening the interpretation of the interstate commerce clause of the Constitution. ${ }^{03}$ Federal control is often justified because the various states cannot deal effectively with a problem requiring uniform regulation, and on this justification the Court is approving an expansion in the scope of the federal police power and limiting private freedom of action. Thus the seminal phrase "affecting commerce" among the states is the condition and authority for the National Labor Relations Board to police labor relations in industry. The broad interpretation accorded that phrase in supporting the control of labor relations leads to the inference that it may not be long before the production and distribution of raw materials and commodities which are going to and have arrived from other states may likewise fall under the federal police power. ${ }^{\text {as }}$ The general welfare clause, now to be given its Hamiltonian construction, foreshadows a wide range of federal control and operation of industry. ${ }^{95}$

Again, we find the taxing power, both state and federal, increasingly sustained as against a former tendency to construe it strictly. ${ }^{\text {Do }}$ So the sovereign halo which had protected the lessees of state lands and state and federal employees and instrumentalities, even professors in state

93. National Labor Relations Board v. Jones \& Laughlin Steel Corp., 301 U. S. I (1937) ; Santa Cruz Fruit Packing Co. v. National Labor Relations Board, 58 Sup. Ct. 656 (1938).

94. Possibly Carter v. Carter Coal Co., 298 U. S. 238 (1936) has already been overruled sub silentio, although the majority does not admit it.

95. Helvering v. Davis, 301 U. S. 619, 641 (1937) (old-age benefits of Social Security Act). Grant, Commerce, Prodiction, and the Fiscal Poxcers of Congress (1936) 44 YALE L. J. 751, 991.

96. Compare Missouri v. Gehner, 281 U.S. 313 (1930) and Baldwin v. MCissouri, 281 U. S. 586 (1930) with Henneford v. Silas MFason Co., 300 U. S. 577 (1937). 
universities, from taxation by the other government, seems likely to evaporate. $^{97}$ In time, even Collector $v$. Day ${ }^{98}$ may be overruled.

Commentators upon the incidence of judicial control over legislation are prone to conclude that the Supreme Court is infinitely more sensitive to encroachments on property rights than on personal privileges. ${ }^{00}$ Possibly so, although in that clear antithesis the charge is hardly provable. The fact may be due to economic determinism, to natural conservatism, or to other causes. But in recent years wide extensions in the use of the police and taxing power to accomplish business regulation have been sustained. Discriminatory taxation based on size or number, as in the chainstore cases, regulation to restrain natural economic advantages, such as control of unfair or effective competition, even the suppression of unwelcome industry, have met with little resistance from a majority of the Supreme Court. The equalitarian philosophy of recent years has had its effect, and courts generally have found it inadvisable to check it.

The constitutional limitations on federal power, the application of such doctrines as the separation of powers, have enabled the Court to invalidate certain New Deal legislation, like the NRA. But even here, nothing that is considered to have a permanent value is likely to be stopped by any opposition of the Supreme Court. The AAA is now with us in another form and if by chance it should prove successful, the Supreme Court will probably find it to be constitutional. The balance between private freedom and the public control will continue to be maintained and the line drawn where public opinion ultimately desires.

\section{V.}

Viewing the work of the Supreme Court in historical retrospect, it can probably be said that it has performed its several functions more satisfactorily than any other department of the Government. Especially for a people like the American is a balance-wheel necessary, and that the Supreme Court has supplied. Its mistakes as judged by the passage of time have been relatively few. Hence the extreme desirability that it should not expose itself to justifiable criticism in the performance of its indispensable functions. It has erred in assuming the function of arbiter of American social and economic policy and in using the due process clause for that purpose. Had it refrained from this encroachment it

97. James v. Dravo Contracting Co., 302 U. S. 134 (1937), Comment (1938) 51 HaRv. L. Rev. 707; Helvering v. Mountain Producers Corp., 58 Sup. Ct. 623 (1938), overruling, and sustaining the minority, in Gillespie v. Oklahoma, 257 U.S. 501 (1922) and Burnet v. Coronado Oil \& Gas Co., 285 U. S. 393 (1932), (1938) 51 Hagv. L. Rev. 1105.

98. 11 Wall. 113 (U. S. 1870).

99. Cf. Edgerton, The Incidence of Judicial Control Over Congress (1937) 22 CoRN. L. Q., 299. 
would probably have been spared the attacks of the past year and would have obtained all the greater prestige for its strictly judicial work. In the long run, also, the attempt to uphold certain types of private interest against the Government's taxation and police power measures have not strengthened those private rights, but have weakened them, for they have become the object of attack in the political arena. Responsibility for the ineptitude or unwisdom of legislation should be left with the legislatures.

The Supreme Court itself and the country will profit by a deflation of the due process clause to normal proportions. A more natural interpretation of the "privileges and immunities" clause would have avoided the temptation to inflate the due process clause, and even now points the way out. ${ }^{100}$ "Due process" is so vague a term as necessarily to invite challenge, when invoked by the Court as a ground for defeating legislation. It obviously implies subjective criteria. Were the Court to build a category of federal "privileges and immunities", it would find itself on less vulnerable ground and the appeal would be to reason and not verbiage. Not all the first eight amendments need be regarded as sacred against state limitation. As indicated in the Palko case, ${ }^{101}$ the Court is drawing a line between the fundamental and the merely procedural guaranties. Anything which would lift part of the load from the indefinable "due process" platform and transfer it to the more comprehensible "privileges and immunities" clause, might relieve the Court of some of the current criticism.

The very magnitude of the power of passing on the constitutionality of legislation carries with it great responsibility. The assumed detachment of the Court from political strife, the obedience rendered to its decrees, the sense of power which the finality of its fiat evokes, doubtless led certain judges to assume the political unassailability of the Court. They therefore, it is believed, abused a function which by its very potentialities should have-been used sparingly and with restraint. The failure to observe the limitations of power has ruined many a man and institution. Had Napoleon resisted the temptation to try the winter sports at Moscow, the history of Europe might have been quite different.

Justice Stone was correct, it is believed, when in his dissenting opinion in the New York Minimum Wage case ${ }^{102}$ he said:

"It is difficult to imagine any grounds other than our own personal economic predilection for saying that the contract of employment is any the less a proper subject of legislation than are scores of others in dealing with which this Court has held that legislatures may curtail individual freedom in the public interest."

100. Cf. Colgate v. Harvey, 296 U. S. 404 (1935).

101. Supra note 75.

102. Morehead v. New York ex rel. Tipaldo, 298 U. S. 587, 633 (1936). 
It was Justice Stone's dissent in the AAA case ${ }^{103}$ to the effect that "the only check upon our own exercise of power is our own sense of selfrestraint", that evoked Justice Sutherland's vigorous protest that such a view was "ill-considered and mischievous". "Self-restraint," he says, "belongs in the domain of will and not of judgment." But if the due process decisions on substantive law prove anything, they demonstrate that the Court's judgment is the product of the will. It is the social and economic predilection which speaks. While the primacy of the public welfare is gradually winning its way and the ever-growing complexity of governmental regulation of business and other activities will probably produce a tolerant attitude toward legislation, the life of the Court will be prolonged by assuming the Holmesian attitude that it is not the Court's function to censor the legislature's finding of an evil or the efficacy of its remedies.

The events of recent years both in this country and abroad have indicated that no institution is invulnerable. It would be a calamity of the first order if the country should forfeit the stabilizing functions of the Supreme Court by reason of an abuse of a function which it was not intended by the due process clause that the Court should exercise. Tolerance of the encroachment is consistent only with a modest use of so vast a power. Thus will the constant practice of running to the Court with the claim of a violation of substantive due process be checked. Thus also will legislatures be obliged to assume greater responsibility for the good sense and the draftsmanship of their legislation and for its practical effectiveness. Thus also will a better governmental balance be restored. The individual will then look to the right quarters for relief. The due process protection of private property and even of civil liberties will cease to be a transitory illusion and thus the sooner will the realities of the balance between public and private interests be faced. From every point of view, therefore, American institutions and the people will profit from the relinquishment by the Supreme Court of its assumed function as the arbiter of social policy. .

103. United States v. Butler, 297 U. S. 1, 79 (1936). 